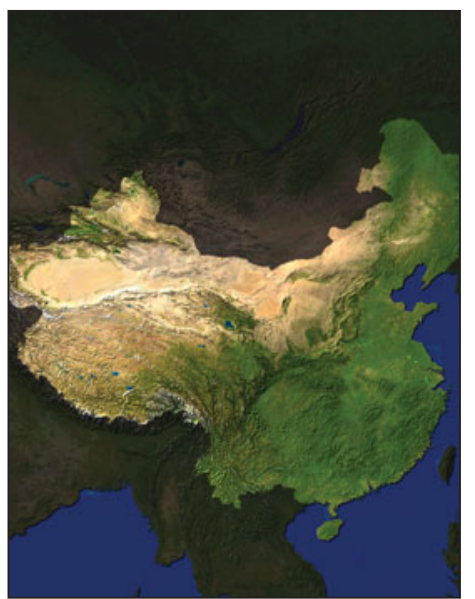

\section{China and} South Africa pursue coal liquefaction

\section{By Prachi Patel}

Feature Editor Rocco Fiato

B eneath the steppes of northern China's Inner Mongolia autonomous region lie some of the world's largest coal deposits. Every year, 3.45 million tons of the black stuff is trucked to a huge factory in Ordos, 150 kilometers south of the region's largest city, Baotou. There it is transformed into 1 million tons of liquid fuels, mainly diesel and gasoline, to satiate some of China's escalating hunger for transport fuels.

China consumed about 250 million tons of gasoline, diesel, and jet kerosene for transport in 2009, according to the International Energy Agency. About half of the petroleum the country needs to make these fuels is imported; imports could go up to $67 \%$ by 2020 . With a burgeoning economy, the largest automobile market in the world, and a dearth of domestic oil, China is turning to its vast coal reserves - 114.5 billion tons at last countto meet the country's oil needs.

Shenhua Group, the owner of the Ordos liquefaction facility, plans to triple the plant's capacity by 2013 . And many other large-scale projects are in the pipeline in China. Three coal-to-liquids (CTL) plants undergoing construction will together pump out close to nine million tons of transport fuels a year. Other companies are building factories to convert coal into synthetic natural gas and chemical commodities such as olefins, methanol, and naphtha that would otherwise be derived from petroleum.

"Coal-to-chemicals is a hot topic in China," said Per Bakkerud, a managing director in Beijing for Danish company Haldor Topsøe, which makes CTL catalysts and is rapidly expanding business in China. "We expect to see a number of projects being approved by the central government in the coming years."

Coal-derived fuels look no different than their petroleum counterparts and work with the same transport pipelines and engines. When burned, they release the same amount of carbon dioxide but fewer sulfur and aromatics emissions. The big downside is the environmental impact from converting coal into fuels. In addition to using copious amounts of water, the process releases twice the amount of carbon dioxide as extracting and refining fuels from petroleum.

Yet, for coal-rich, oil-poor countries such as China, the proven, decadesold technology promises independence from foreign oil. It also makes economic sense: CTL fuels are competitive with petroleum at $\$ 50$ a barrel.

While Australia, Indonesia, and the United States are investigating the technology, China has become only the second country in the world after South Africa to adopt CTL on a commercial scale. And with mounting climate change and resource use concerns, the Chinese government and industry aim to reduce the environmental footprint of making fuels from coal.

Coal liquefaction technology dates back to Germany in the 1920s. In 1923, Franz Fischer and Hans Tropsch discovered what remains to be the most common process for making synthetic liquid fuel today. Fischer-Tropsch synthesis, also called indirect liquefaction, involves gasifying coal to give a mixture of carbon monoxide and hydrogen that is fed into a reactor where it is heated in the presence of iron-based catalysts. The process yields mostly saturated hydrocarbons such as diesel and jet fuels. Germany relied on this technology in the 1940s for a secure source of transport fuels.

In the 1950s, the technology was widely adopted in South Africa. The South African chemical company Sasol developed new reactor technologies that increased the efficiency of the FischerTropsch process, yielding higher quantities of desired products at lower costs. Sasol opened the world's first commercial CTL plant in 1953. Two other plants were commissioned in the 1980s.

The company still produces 8.8 million tons of crude oil equivalent a year at these plants, providing nearly $40 \%$ of South Africa's transport fuels. It is also expanding its global reach, building new natural gas-to-liquids plants in Qatar and Nigeria and undertaking feasibility studies in the United States and Canada.

Globally, CTL's popularity has fluctuated with petroleum rates. Price spikes in the 1970s led to significant CTL research pushes by the United States, Europe, Australia, and Japan, but efforts tapered off by the early 1990s as oil prices stabilized. With current high oil prices and the need for energy security, liquefaction is seeing a rebirth.

China's increasing need for energy is driving innovation and development. Thousands of researchers at universities across China are working on better reactor designs and low-cost, ultrahigh-efficiency catalysts. The government is investing billions of dollars in the demonstration and adoption of various coal-to-chemical technologies. "China is the most promising playground for introducing new technologies," Bakkerud said.

Shenhua operates two plants that transform coal into olefins. Seven more coalto-olefin plants are scheduled for completion by 2015 . Many coal-to-methanol plants exist, and one of these converts methanol into olefins. Three large-scale 
projects to transform coal into synthetic natural gas are also under construction. All told, coal could provide about 25 billion cubic meters of natural gas, 10 million tons of methanol, and six million tons of olefins by 2015, according to Shanghai-based independent consulting organization AsiaChem. That will only meet a fraction of China's needs, which include a projected 350 billion cubic meters of natural gas by 2020 and 50 million tons of methanol by 2015 .

Most upcoming CTL plants in China will employ indirect liquefaction. Produc-
Direct liquefaction can reach thermal efficiencies of $75 \%$ compared to around $40 \%$ for indirect liquefaction. It also yields more and cleaner burning gasoline and jet fuel. But the crude products need refining to meet fuel quality standardsdiesel from the process, for instance, does not meet European standards. Still, the efficiency advantage makes the direct approach desirable "to maximize liquid fuel out of a coal resource, especially if you want to make gasoline or jet fuel," said Richard Bauman, vice president of technology at Houston, Texas-based Accel-

tion yields two barrels of liquid fuel per ton of coal and direct liquefaction gives three barrels, Accelergy's approach could yield up to 3.6 barrels, Bauman said. The company has gained a nod from the Inner Mongolian government for an 82,000 barrels-per-day plant and is now awaiting approval from China's National Development and Reform Commission (NDRC).

Desks at the NDRC are piled high with applications for coal liquefaction plants, said Sun, but the government has not been generous in granting approvals: only two projects were given the go-ahead in 2011.

The reason is mainly because of high carbon emissions and water use. Indirect technologies require 7-12 barrels of water for every barrel of product. Even more efficient direct technologies need 3-4 barrels of water.

In South Africa, Sasol's plants currently vent carbon dioxide into the air, even though the company has the technological competence to capture the gas and sequester it underground. Many Chinese liquefaction plant-owners, meanwhile, have expressed willingness to capture and sequester carbon dioxide, but none do it at a large scale. Shenhua operates a small demonstration project at

ers in China have taken the technology further than Sasol, developing advanced bimetallic iron- and molybdenum-based catalysts that generate higher quantities of specific products and are easier to recycle, bringing down costs. "If you consider, for example, one ton of catalyst, the Chinese technology might produce 10 tons of oil, and Sasol would produce two tons," said Qingyun Sun, associate director of the U.S.-China Energy Center at West Virginia University.

China is also investing in the lessdeveloped but more energy-efficient direct liquefaction technology, which skips gasification and instead directly converts coal to a partially refined synthetic crude in the presence of heat, hydrogen, and catalysts. The process only works with high-grade coal (plentiful in Inner Mongolia) that has fewer minerals and metals that would otherwise have to be removed. ergy Corporation, which has developed a new approach to direct liquefaction.

Shenhua's Ordos plant employs direct liquefaction. Utah-based Headwaters Incorporated, which provided part of the plant's technology, is now testing its direct liquefaction method for other clients in China, India, and Indonesia. Both Shenhua and Headwaters first mix pulverized coal with recycled oil product and high-pressure hydrogen (derived from coal or undesired hydrocarbons produced during liquefaction) at high temperatures of over $450^{\circ} \mathrm{C}$, which breaks down the coal structure. A second reactor then liquefies the slurry.

Accelergy, on the other hand, uses a proprietary microcatalyst in parts-permillion concentration and employs three smaller reactors in series. Their pilot plant near Beijing reaches thermal efficiencies close to $68 \%$. While indirect liquefacits direct liquefaction plant, sequestering 100,000 tons of carbon dioxide into a deep-saline aquifer every year. Over $86 \%$ of its annual four million tons of carbon dioxide emissions are capture-ready, but cost remains a major hurdle.

Because of China's rapid growth, it faces increased pressure to tackle climate-warming emissions. The NDRC's latest five-year plan aims for a $17 \%$ reduction in carbon emissions per unit gross domestic product by 2015 .

In tackling emissions, approaches such as Accelergy's could have an advantage. The company plans to use carbon dioxide to grow local algae, which is mixed with additives to make a biofertilizer. "We can spray it on farmland or arid land, where it acts as a fertilizer and soil improver," Bauman said, "and since it continues to grow, it continues to take carbon dioxide out of the air." 


\section{Correction of cyanobacteria misinformation could improve biofuels production}

Science DOI: $10.1126 /$ science. 1210858

The discovery of two enzymes in cyanobacteria that do the work of one missing enzyme has opened new possibilities for genetically engineering bacteria to produce biofuels more efficiently than currently available methods. As reported by Donald Bryant and Shuyi Zhang of The Pennsylvania State University in a recent issue of Science, research done in 1966 concluded that a missing enzyme in cyanobacteria prevented the completion of the tricarboxylic acid (TCA, or Krebs) cycle, which helps to break down biomass through oxidation. This ostensibly rendered the organisms incapable of oxidizing metabolites for energy production. By taking a look 44 years later using modern instrumentation and enhanced biochemical and genetics tools, Bryant and his team discovered two enzymes that perform the same task of the missing enzyme, completing the TCA cycle by a slightly different path. Equipped with this new understanding of how cyanobacteria make energy, the next step for the researchers is to determine how to genetically engineer a cyanobacterial strain to synthesize 1,3-butanediolan organic precursor for making biofuels.

\section{Quantum dot paint acts as a solar cell}

ACS Nano DOI: $10.1021 / \mathrm{nn} 20438 \mathrm{lg}$

Researchers at the University of Notre Dame in Indiana, led by Prashant V. Kamat, have developed what they call "SunBelievable" solar paint, using $\mathrm{TiO}_{2}$ nanoparticles coated with $\mathrm{CdS}$ and CdSe quantum dots as the solar energy absorbing constituents. Using a pseudo-SILAR (sequential ionic layer absorption and reaction) approach, they deposited $\mathrm{Cd}_{2}+$ along with $\mathrm{S}_{2}-$ or $\mathrm{Se}_{2}-$ onto suspended $\mathrm{TiO}_{2}$ nanoparticles. Mixing these particles with a tert-butyl alcohol/water solution produced a yellow paint that could be applied in a one-step, brush-

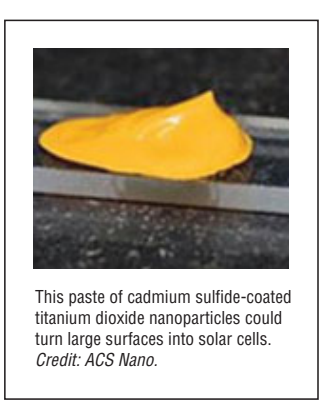
on process to conducting glass electrodes to form photoanodes. Subsequent photoelectrochemical characterization revealed a rapid photoresponse in each paint type, with photocurrent generation efficiencies of $30-40 \%$. A paint mixture containing both $\mathrm{CdS} / \mathrm{TiO}_{2}$ and $\mathrm{CdSe} / \mathrm{TiO}_{2}$ yielded the best power conversion efficiency of $1 \%$.

Although admitting this figure is very low, Kamat said the low cost and the ease of making the solar paint in large quantities could make it a viable solar energy technology if the efficiency can be increased by a moderate amount in the future.

\section{Alane stores hydrogen at high capacity}

http://srnl.doe.gov

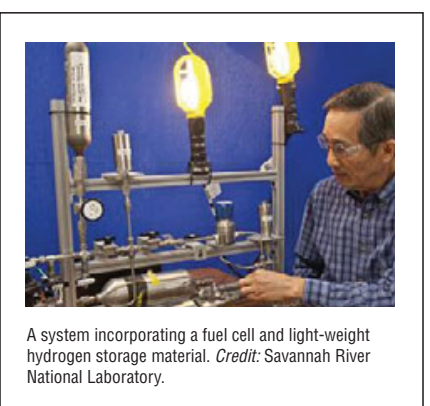

With the goal of producing a portable power system small and lightweight enough for soldiers to carry in their backpacks or to power a lightweight drone aircraft, scientists Ted Motyka, Ragaiy Zidan, and Kit Heung at the U.S. Department of Energy's

Savannah River National Laboratory are studying alane (aluminum hydride, $\mathrm{AlH}_{3}$ ) as a hydrogen storage material for portable fuel cells. Alane can store twice as much hydrogen, in the same volume, as liquid hydrogen, with a high gravimetric capacity of $10 \mathrm{wt} \%$, making it a great candidate for portable systems. To date, researchers have developed a method of producing alane that minimizes the use of solvents and yields pure, halide-free alane at a lower cost than traditional synthesis methods. They also have invented a two-step process that releases twice as much hydrogen from alane as the previous one-step process. In a promising demonstration, a system containing 240 grams of alane was able to operate a 150 -watt commercial fuel cell at near full power for over three hours.

\section{Methane eliminates $\mathrm{CO}_{2}$ in coal gasification}

http://sri.com

Using methane as a component of a coal-to-liquids process could lead to lower energy consumption and eliminate the need to add water, since methane can replace water as the source of hydrogen necessary to produce syngas $\left(\mathrm{H}_{2}\right.$ plus $\left.\mathrm{CO}\right)$, a precursor to liquid fuels. As reported by Ripudaman Malhotra, associate director of the Chemical Science and Technology Laboratory at SRI International in Menlo Park, Calif., at the 28th annual International Pittsburgh Coal Conference, the process is environmentally friendly because it does not produce the greenhouse gas $\mathrm{CO}_{2}$ as in other syngas-based processes, such as Fischer-Tropsch synthesis. The process, called "coal gasification with methane reforming," eliminates the need to combust a portion of the coal feed to produce energy to power the conversion. Instead, electricity from renewable sources could be supplied to gasify the coal, thus eliminating the combustion step that forms $\mathrm{CO}_{2}$. Though these results are based on bench-scale experiments and are therefore preliminary, the researchers calculate that the capital cost of a full-scale plant based on this technology could be about half that of a Fischer-Tropsch plant. 